\title{
Korean Journal of Environmental Agriculture
}

Korean J Environ Agric (2012)

Online ISSN: $2233-4173$

Vol. 31, No. 1, pp. 9-15 http://dx.doi.org/10.5338/KJEA.2012.31.1.9

Print ISSN: $1225-3537$

Research Article

Open Access

\section{제주지역 일부 농업 시설 내 라돈 농도 예비 조사}

\author{
강태우, ${ }^{1 *}$ 송명한, ${ }^{2}$ 김태형, ${ }^{3}$ 장병욱, ${ }^{2}$ 김용재, ${ }^{2}$ 김근호, ${ }^{3}$ 박재우 ${ }^{4 * \star}$ \\ ${ }^{1}$ 제주대학교 원자력과학기술연구소, ${ }^{2}$ 한국원자력안전기술원, ${ }^{3}$ 한국원자력연구원, ${ }^{4}$ 제주대학교 에너지공학과
}

\section{A Preliminary Investigation of Radon Concentration for Some Agricultural Greenhouses in Jeju Island}

Tae-Woo Kang, ${ }^{1 *}$ Myeong-Han Song, ${ }^{2}$ Tae-Hyoung Kim, ${ }^{3}$ Byung-Uck Chang, ${ }^{2}$ YoungJae Kim, ${ }^{2}$ Geun-Ho Kim ${ }^{3}$ and Jae-Woo Park ${ }^{4 *}\left({ }^{1}\right.$ Institute for Nuclear Science and Technology, Jeju National University, Jeju 690-756, Korea, ${ }^{2}$ Korean Institute of Nuclear Safety, Daejon 305-338, Korea, ${ }^{3}$ Korea Atomic Energy Research Institute, Daejon 305-353, Korea, ${ }^{4}$ Department of Nuclear and Energy Engineering, Jeju National University, Jeju 690-756, Korea)

Received: 5 March 2012 / Accepted: 23 March 2012

(c) 2012 The Korean Society of Environmental Agriculture

\begin{abstract}
BACKGROUND: A preliminary investigation of the radon $\left({ }^{222} \mathrm{Rn}\right)$ concentration has been conducted, employing solid-state nuclear-track detectors (SSNTD) and a continuous radon monitor (CRM), for fourteen randomly selected agricultural greenhouses in Jeju Island, where the underground-air was used for air conditioning and $\mathrm{CO}_{2}$ supplement.
\end{abstract}

METHODS AND RESULTS: The SSNTD was used to measure the average radon concentration for three months and the CRM was used for an instantaneous measurement. In order to obtain the radon concentration of a greenhouse, the SSNTDs were placed at a number of evenly distributed points inside the greenhouse and the mean of the measured values was taken. In addition, in order to assess the radon concentration of the underground-air itself, measurement was also made at the borehole of the underground-air in each agricultural facility, employing both the SSNTD and CRM. It is found that the radon concentration of the greenhouses ranges higher than those not using the

*교신저자(Corresponding author),

Phone: +82-64-756-1866; Fax: +82-64-755-6186;

E-mail: cjkins@hanmail.net

**공동교신저자(Corresponding author),

Phone: +82-64-754-3645; Fax: +82-64-757-9276;

E-mail:jwpark@jejunu.ac.kr underground-air and the average of Korean dwellings. While the radon concentration of most agricultural facilities is still lower than the reference level $\left(1,000 \mathrm{~Bq} / \mathrm{m}^{3}\right)$ recommended by the International Radiation Protection Committee (ICRP), three facilities at one site show higher concentrations than the reference level. The three-monthaveraged radon concentration and the instantaneous radon concentration of the underground-air itself ranges 1,2285,259 and 3,322-17,900 Bq/ $\mathrm{m}^{3}$, respectively, and regional variation is more significant.

CONCLUSION: From this results, radon concentration of the underground-air is assumed that it is associated with the geological characteristics and the boring depth of the region located of their.

Key Words: Agricultural facility, Greenhouse, Radon, ${ }^{222} \mathrm{Rn}$, Underground-air

\section{서 론}

고온성 작물인 감귤 가온 온실 농가가 밀집한 제주지역은 최근 국제유가의 폭등으로 인한 농업 경영비의 증가로 농업 경쟁력이 저하되어 농가에 큰 타격을 주고 있다. 이러한 이유 로 일부 온실 농가에서는 연중 온도가 $14 \sim 22^{\circ} \mathrm{C}$ 로 일정하고, 대기에 비해 상대적으로 $\mathrm{CO}_{2}$ 농도가 높은 지하 40 80 m 지 점의 화산암층(암반층)에 분포하고 있는 화산쇄설층의 지하공 기를 활용하고 있다(Kang et al., 2009). 지하공기의 이용은 화석 연료의 사용을 감소시켜 온실가스 감축은 물론 농업 경 
쟁력에도 많은 도움을 주고 있는 것으로 평가되고 있다(Oh et al., 2000; Booh et al., 2006). 지하공기는 화산쇄설층 및 개방형 절리 비율이 낮은 산방산군에 속하는 조면암류 분포 지역과 표고가 $25 \mathrm{~m}$ 이하로 지하수층과의 길이가 짧아 시추 심도가 길지 않은 곳을 제외하고는 제주지역 내 $85 \%$ 가 활용 이 가능하다고 보고하였고, 농축산 산업에 활용 가능성이 크 다고 제안하였다(RDA, 2008; Kang et al., 2009). 하지만, 이러한 지하공기에는 자연적으로 발생하는 방사성 기체인 라 돈 $\left.{ }^{222} \mathrm{Rn}\right)$ 이 포함되어 있어 밀폐된 공간인 온실에 강제로 유 입시킬 경우 라돈 농도가 매우 높아질 수 있기 때문에 온실 작업자들의 자연방사선 피폭량을 증가시키는 요인이 될 수 있다.

라돈은 암석이나 토양에 함유되어 있는 지구기원의 천연 방사성 핵종인 우라늄 $(238)$ 의 방사성 붕괴 계열에서 생성되 는 무색, 무취, 무미의 불활성 기체로 흡연 다음으로 폐암을 유 발하는 원인물질로 잘 알려져 있다(ICRP 1993; UNSCEAR, 1993). 우리나라 국민이 평균적으로 받는 자연방사선원에 의 한 연간 유효선량 $3.08 \mathrm{mSv} / \mathrm{y}$ 중에서 약 46\%(1.40 $\mathrm{mSv} / \mathrm{y}$ )가 라돈과 라돈의 방사성 붕괴 생성물(자핵종)의 흡 입에 의한 체내피폭으로 알려져 있다(KINS, 2009). 라돈은 라듐 $\left.{ }^{226} \mathrm{Ra}\right)$ 의 방사성 붕괴에 의해 생성되어 암석이나 토양의 공극을 통해 지표로 방출되고, 건축물 바닥의 균열이나 틈 (85 90\%), 건축자재에서 방출(2 5\%), 확산(1 4\%), 지하수 (1\% 이하) 등을 통해 실내로 유입된다(UNSCEAR, 2000). 일반적으로 현무암이 넓게 분포하는 제주지역의 실내 라돈 농도는 내륙에 비해 상대적으로 낮은 것으로 알려져 있으나 (KINS, 2007; Kim et al., 2011), 제주지역의 지하 하부에는 기반암으로 화강암이 존재하고, 기공 발달이 많으며, 균열과 수직절리가 잘 발달되어 있어 상대적으로 실내 라돈 농도가 높은 경우도 있다(KINS, 2005).

전 세계적으로 라돈에 대한 연구는 일반적인 주거시설에 초점을 맞추고 있으며 일부 지하시설(광산, 채굴장, 지하철, 쇼핑몰 등)에서의 직무상 피폭이 관심의 대상이 되어 왔다. 또한 각 국가별로 전국 규모의 실태 조사에 의한 라돈지도 작 성과 함께 건강 위해성 평가를 통해 실내 라돈 관리를 위한 권고기준을 설정하고, 이를 저감하기 위한 연구가 활발히 진 행되어 왔다. 최근, 일본과 이집트에서는 온실 내 라돈 농도 를 조사함으로써 실내 라돈 조사 대상이 농업 환경에까지 광 범위하게 확대되어 연구되고 있는데(lyogi et al., 2006; Abd El-Zaher et al., 2008), 라돈에 대한 관심도가 낮아 아직까 지는 미흡한 실정이다. 특히, 제주지역과 같이 지하공기를 온 실 내에 강제로 유입시켜 활용하는 사례는 전 세계적으로 거
의 찾아보기 어렵다. 국내 농업 분야는 온실 단지화로 변화하 면서 점차 집단화가 이루어져 온실에서 종사하는 작업자들이 증가하는 추세임에도 불구하고 이러한 시설들에 대한 라돈 농도 조사는 거의 전무한 실정으로 자연방사선 피폭에 대한 방사선 방호 측면에서 작업자들의 라돈과 라돈 자핵종 흡입 에 의한 건강 위해성 평가 및 이를 위한 라돈 실태 조사는 절 대적으로 필요한 사안이다.

따라서, 본 연구는 제주지역에서 지하공기를 이용하는 일 부 농업 시설을 대상으로 지하공기 이용 온실 및 미이용 공간 내 라돈 농도와 지하공기 이용 시설의 가동에 따른 지하공기 유입구 라돈 농도의 지역적인 분포를 조사함으로써 농업 시 설에 대한 라돈 농도를 국내에서 처음 시도하였다는 데 그 의 의가 크다.

\section{재료 및 방법}

제주지역에서는 농업, 축산업, 임업 등 여러 분야에서 온 실 내 냉난방 및 $\mathrm{CO}_{2}$ 공급을 목적으로 약 413개(2008년 기 준)의 지하공기 이용 시설이 설치되어 제한적으로 이용되고 있다(Kang et al., 2009). 본 연구에서는 지하공기 이용 시설 을 설치하여 운영하고 있는 농업 시설 가운데 상대적으로 규 모가 크고, 지하공기 이용 시설의 가동 빈도가 높은 14 개 농 업 시설을 선정하여 지하공기 이용 시설의 유입구와 온실 내 라돈 농도 조사를 수행하였다(Fig. 1). 조사대상 농업 시설은 대부분 화훼 및 과채류를 재배하고 있었으며, 일부 시설은 버 섯재배에도 활용되고 있었다(Table 1).

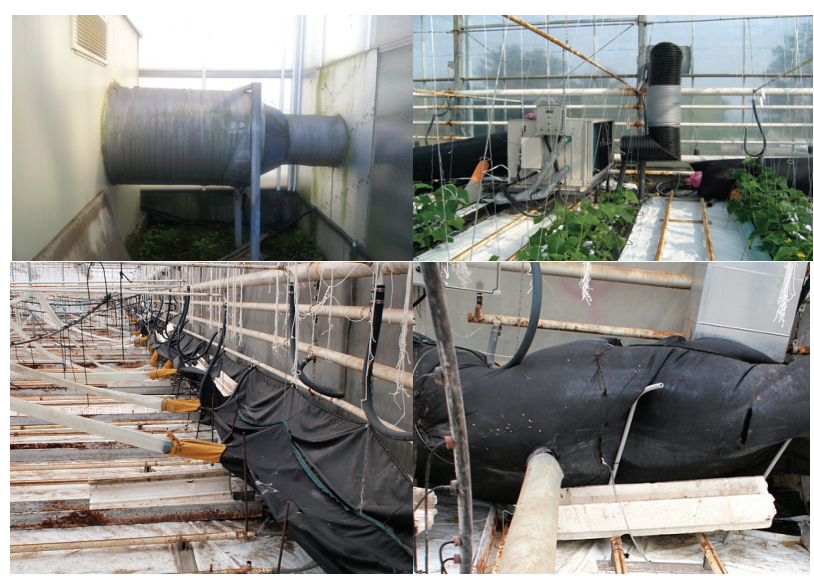

Fig. 1. The photographs of a typical greenhouse using the underground-air 
Table 1. Summary of the greenhouse selected for the investigation of the radon concentration.

\begin{tabular}{|c|c|c|c|c|c|c|c|}
\hline \multirow{2}{*}{ Site } & \multirow{2}{*}{ City } & \multirow{2}{*}{ Group $^{\mathrm{a})}$} & \multirow{2}{*}{ Produce } & \multirow{2}{*}{$\begin{array}{l}\text { Area } \\
\text { (ha) }\end{array}$} & \multicolumn{2}{|c|}{ Borehole } & \multirow{2}{*}{ Density } \\
\hline & & & & & Depth (m) & No. ${ }^{b} /$ No. $^{c)}$ & \\
\hline$A$ & \multirow{8}{*}{ Jeju-si } & Large & Fruit vegetables & 0.99 & 80 & $2 / 1$ & 2.0 \\
\hline B & & Small & Fruit vegetables & 0.25 & 70 & $1 / 1$ & 4.0 \\
\hline C & & Small & Fruit vegetables & 0.43 & 50 & $1 / 1$ & 2.3 \\
\hline D & & Small & Fruit vegetables & 0.26 & 40 & $1 / 1$ & 3.8 \\
\hline$E$ & & Small & Floricultural crop & 0.31 & 50 & $1 / 1$ & 3.2 \\
\hline $\mathrm{F}$ & & Small & Mushroom & 0.099 & 35 & $1 / 2$ & 10 \\
\hline G & & Large & Fruit vegetables & 1.15 & $40-60$ & $7 / 1$ & 6.1 \\
\hline $\mathrm{H}$ & & Large & Floricultural crop & $0.01-0.26$ & 60 & $3 / 4$ & 11 \\
\hline 1 & \multirow{6}{*}{ Seogwipo-si } & Small & Floricultural crop & 0.26 & 40 & $1 / 1$ & 3.8 \\
\hline$J$ & & Small & Floricultural crop & 0.26 & 40 & $1 / 1$ & 3.8 \\
\hline $\mathrm{K}$ & & Large & Fruit vegetables & 0.99 & 40 & $2 / 1$ & 2.0 \\
\hline$L$ & & Small & Floricultural crop & 0.17 & $40-50$ & $1 / 1$ & 5.9 \\
\hline M & & Small & Fruit vegetables & 0.33 & 50 & $1 / 1$ & 3.0 \\
\hline $\mathrm{N}$ & & Small & Fruit vegetables & 0.40 & 40 & $1 / 1$ & 2.5 \\
\hline
\end{tabular}

${ }^{\text {a) }}$ Classification based on the number of workers (Small is under 5 workers, Large is more than 5 workers)

b) The number of boreholes in greenhouse

${ }^{c}$ The number of greenhouses using underground air

d) The number of boreholes per area (ha)

지하공기 이용 시설의 지하공기 유입구와 온실 내 라돈 농 도는 14 개 농업 시설 중 11 개 시설에서 수동형 알파입자비적 검출기(Raduet, Radosys Ltd., Hungary)를 이용하여 2010 년 5월부터 8월까지 약 3개월 동안 측정하였으며, 지하공기 이용 시설의 설치 유무에 따른 라돈 농도 차이를 비교하기 위 하여 지하공기를 이용하지 않는 공간(온실, 펌프실 및 사무실) 에도 조사하였다. 조사대상 농업 시설은 작업자 수를 기준으 로 소형(5인 미만) 및 대형 시설(5인 이상)로 구분, 대형시설 의 경우는 지하공기 이용 온실의 내부를 더욱 세분화하여 온 실의 공간특성 및 근무자의 작업 환경을 고려하여 검출기를 설치하였다(Fig. 2). 수동형 알파입자비적 검출기는 검출기 챔버 내부로 유입된 라돈이 방사성 붕괴에 의해 생성되는 알 파붕괴 핵종 ${ }^{218} \mathrm{Po},{ }^{214} \mathrm{Bi}$ 및 $\left.{ }^{214} \mathrm{Po}\right)$ 이 방사성 붕괴할 때 방출 되는 알파입자 $\left({ }^{4} \mathrm{He}\right.$ 핵)의 에너지에 의해 검출 물질인 CR-39 (Polyallyl Diglycol Carbonate) 플라스틱 칩 표면이 손상 되어 생성되는 미세한 비적을 계수하여 라돈 농도를 산출한 다. 일정기간 특정 공간에서 노출시킨 검출기는 회수하여 검 출기의 챔버로부터 CR-39 플라스틱 칩을 분리하여 $90^{\circ} \mathrm{C}$ 의 $6.25 \mathrm{M} \mathrm{NaOH}$ 수용액에서 4시간 30분 동안 화학적 에칭 과 정을 거쳤다. 이 과정에서 CR-39 플라스틱 칩 표면은 화학적 으로 부식되어 알파입자 비적이 확대되고 선명해져 판독이 가 능하게 된다. 에칭 과정이 완료된 CR-39 플라스틱 칩은 건조 시킨 후 광학현미경이 내장된 자동 비적판독 시스템(RSV-6, Radosys Ltd., Hungary)으로 판독하였고, 계수된 비적 수 를 이용하여 라돈 농도를 산출하였다(Tokonami et al., 2005; Hulber, 2009).

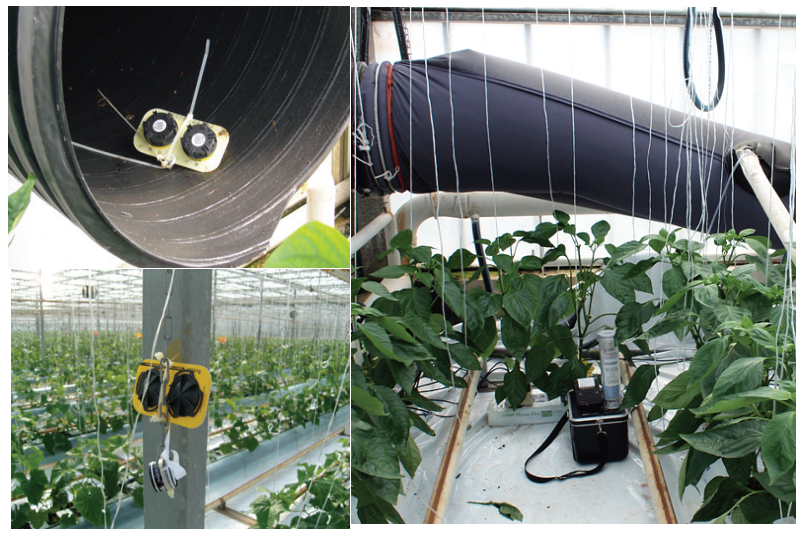

Fig. 2. The photographs of SSNTDs (left) and CRM (right) placed to measure the radon concentration

지하공기 이용 시설의 가동에 따른 유입구의 라돈 농도 분 포는 14 개 농업 시설 중 13 개 시설에서 능동형 연속측정 검 출기(RAD7, Durridge Co., USA)를 사용하였고, 지하공기 이용 시설이 가동되는 시간 동안(약 1 2시간) 10 분 간격으로 유입구 내에서 라돈 농도를 측정하였다(Fig. 2). 능동형 연속 측정 검출기는 외부공기를 검출기의 챔버 내부로 순환시켜 유입된 라돈의 방사성 붕괴에 의해 생성되는 자핵종 가운데 일부 알파붕괴 핵종 $\left({ }^{218} \mathrm{Po}\right.$ 및 $\left.{ }^{214} \mathrm{Po}\right)$ 의 방사성 붕괴 시 방출되 는 알파입자의 검출 횟수를 계수하여 라돈 농도를 산출한다. 본 연구에서는 ${ }^{218} \mathrm{Po}$ 의 방사성 붕괴 시 방출되는 알파입자의 수를 라돈 농도로 역산하였기 때문에 검출기 챔버에서 라돈 과 ${ }^{218} \mathrm{PO}$ 사이에 방사평형에 소요되는 시간을 감안하여 측정 
초기 30 분 동안의 결과를 제외한 후 평균하여 결과를 도출하 였다.

\section{결과 및 고찰}

수동형 알파입자비적 검출기를 이용하여 측정된 농업 시 설의 지하공기 유입구내 라돈 농도는 1,228 5,259 Bq/m ${ }^{3}$ 의 범위를 보였고, 일부 시설(F, H 및 J 시설)을 제외한 대부분 은 비슷한 경향을 보였다. 유입구 내 라돈 농도는 농업 시설 이 위치한 지역의 지질 특성 이외에도 지하공기 이용 시설의 가동 빈도와 시추공의 깊이 등 복합적으로 영향을 받는 것으 로 판단되지만, 본 연구의 결과만으로는 명확한 판단을 할 수 없었다. 각 농업 시설의 지하공기 이용 온실 내 라돈 농도는 86.0 2,181 Ba/m $\mathrm{m}^{3}$ 의 범위로 본 연구에서 조사된 농업 시설 들 간에 차이가 컸다. $A, E$ 및 $K$ 시설의 경우, 지하공기 유입 구의 라돈 농도는 다른 시설과 비슷하였으나 온실 내 라돈 농 도는 다른 시설에 비해 상대적으로 낮았다. 이러한 것은 지하 공기 이용 온실의 면적(ha)당 시추공의 수가 적어 온실로 유
입되는 라돈의 양이 다른 시설에 비해 상대적으로 적었기 때 문인 것으로 생각된다(C 시설의 경우, 유입구의 라돈 농도 측 정이 수행되지 않았기 때문에 비교 대상에서 제외함). 반면 $\mathrm{F}$ 시설의 경우는 지하공기 유입구의 라돈 농도가 다른 시설에 비해 상대적으로 낮았으나, 온실 내 라돈 농도는 일부 시설과 비슷하거나 높았다. 이것은 환기가 필요하지 않은 재배 작물 (버섯)의 생장특성에 의한 것으로 지하공기를 이용하는 온실 내 라돈 농도는 환기에도 영향을 받는 것으로 판단된다. 지하 공기를 이용하지 않는 공간인 펌프실 내 라돈 농도는 129 $421 \mathrm{~Bq} / \mathrm{m}^{3}$ 의 범위를 보였는데, 다른 미이용 공간인 온실이 나 사무실에 비해 상대적으로 라돈 농도가 높았다. 이는 지하 공기 이용 시설이 가동될 때 지하공기가 일부 펌프실로 유입 되었기 때문이라 생각된다. 다른 지하공기 미이용 시설(온실 및 사무실) 내 라돈 농도는 7.98 127 Bq/m $\mathrm{m}^{3}$ 의 범위를 보였 고, 일부 시설(G 시설 사무실 및 $\mathrm{L}$ 시설 온실)을 제외한 대부 분 시설에서는 국내 가옥의 평균 실내 라돈 농도(55.5 $\mathrm{Bq} / \mathrm{m}^{3}$ )보다 낮았다(Table 2) (KINS, 2005).

Table 2. The long term radon concentration measured with SSNTDs.

\begin{tabular}{|c|c|c|c|c|c|}
\hline \multirow{3}{*}{ Site } & \multicolumn{5}{|c|}{ Radon concentration $\left(\mathrm{Bq} / \mathrm{m}^{3}\right)$} \\
\hline & \multirow{2}{*}{ Borehole } & \multirow{2}{*}{$\begin{array}{c}\text { Using underground-air } \\
\text { Greenhouse }\end{array}$} & \multicolumn{3}{|c|}{ Not using underground-air } \\
\hline & & & Greenhouse & Pump-station & Office \\
\hline$A$ & $3,406 \pm 32^{a)}$ & $121 \pm 28$ & $-{ }^{b)}$ & - & $17.7 \pm 2.4$ \\
\hline $\mathrm{B}$ & $3,196 \pm 31$ & $417 \pm 11$ & - & - & $10.5 \pm 2.0$ \\
\hline C & - & $95.5 \pm 72.2$ & $7.98 \pm 1.81$ & - & $17.0 \pm 2.4$ \\
\hline$E$ & $3,118 \pm 34$ & $86.0 \pm 5.7$ & $67.7 \pm 5.1$ & - & - \\
\hline $\mathrm{F}$ & $1,228 \pm 21$ & $553 \pm 369$ & - & - & $40.6 \pm 4.0$ \\
\hline G & $3,386 \pm 31$ & $718 \pm 233$ & - & - & $86.1 \pm 5.1$ \\
\hline $\mathrm{H}-1$ & $5,259 \pm 47$ & $1,757 \pm 27$ & - & $421 \pm 13$ & - \\
\hline $\mathrm{H}-2$ & $5,092 \pm 46$ & $2,181 \pm 30$ & - & $328 \pm 12$ & - \\
\hline $\mathrm{H}-3$ & $5,044 \pm 46$ & $1,419 \pm 418$ & - & - & - \\
\hline I & $3,328 \pm 35$ & $436 \pm 13$ & - & $129 \pm 7$ & - \\
\hline J & $4,555 \pm 41$ & - & - & $171 \pm 8$ & - \\
\hline K & $3,087 \pm 30$ & $134 \pm 18$ & $51.0 \pm 4.0$ & - & $25.2 \pm 3.0$ \\
\hline L & $3,475 \pm 36$ & $819 \pm 17$ & $127 \pm 7$ & - & - \\
\hline
\end{tabular}

a) Uncertainty

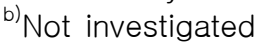

대형시설인 $\mathrm{A}, \mathrm{G}, \mathrm{H}$ 및 $\mathrm{K}$ 시설의 경우 세분화하여 측정 된 라돈 농도는 A 시설의 경우 $89.0 \sim 165 \mathrm{~Bq} / \mathrm{m}^{3}$ (Fig. 3), G 시 설인 경우 114 1,106 Bq/m ${ }^{3}$ (Fig. 4), $\mathrm{H}$ 시설인 경우 1,124 $2,181 \mathrm{~Bq} / \mathrm{m}^{3}$ (Fig. 5) 및 $\mathrm{K}$ 시설의 경우 $111 \sim 160 \mathrm{~Bq} / \mathrm{m}^{3}$ 의 범위를 보였다(Fig. 6). 각 시설의 지하공기 이용 온실 내 라돈 농도는 지하공기 유입구 주변이 가장 높고, 유입구로부터 멀어 질수록 낮아지는 경향을 보였다. 온실 면적과 지하공기 이용 시설의 수 및 가동 빈도가 유사한 $\mathrm{A}$ 및 $\mathrm{K}$ 시설은 지하공기 유입구와 온실 내 라돈 농도가 비슷하였다. 그러나 $\mathrm{G}$ 시설은
$\mathrm{A}$ 및 $\mathrm{K}$ 시설과 유입구의 라돈 농도는 비슷하였으나 온실 내 라돈 농도는 상대적으로 높았는데, $\mathrm{A}$ 및 $\mathrm{K}$ 시설에 비해 온실 면적(ha) 당 시추공의 수가 많아 온실로 유입되는 라돈 양이 상 대적으로 많았기 때문인 것으로 판단된다. $\mathrm{H}$ 시설은 형태와 면 적이 비슷한 3개의 독립된 지하공기 이용 온실 $(\mathrm{H}-1, \mathrm{H}-2$ 및 $\mathrm{H}-3$ )로 구성되어 있고, 각각의 온실에 지하공기 이용 시설이 설치되어 24시간 가동되고 있었다. 각 온실의 지하공기 유입구 의 라돈 농도는 서로 비슷하였으나, 다른 시설들보다는 상대적 으로 높았다. 이러한 것은 지하공기 이용 시설의 가동 빈도가 


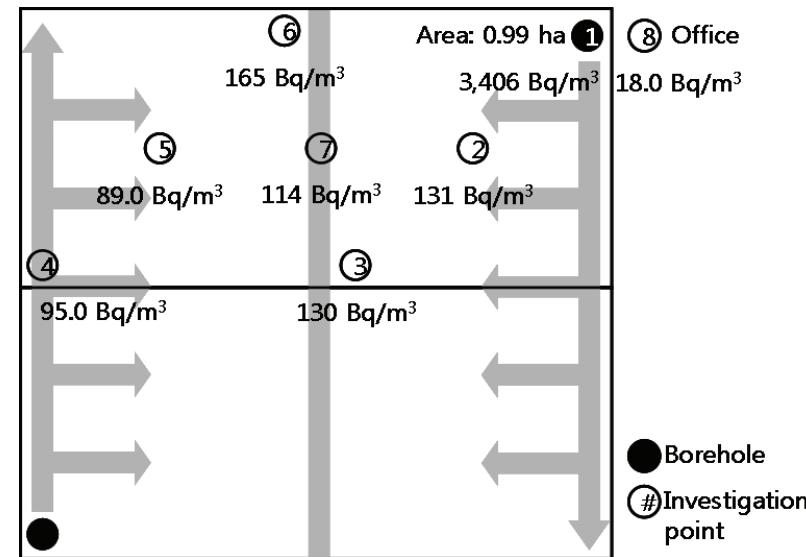

Fig. 3. The long term radon concentrations measured with SSNTDs in the A site greenhouse

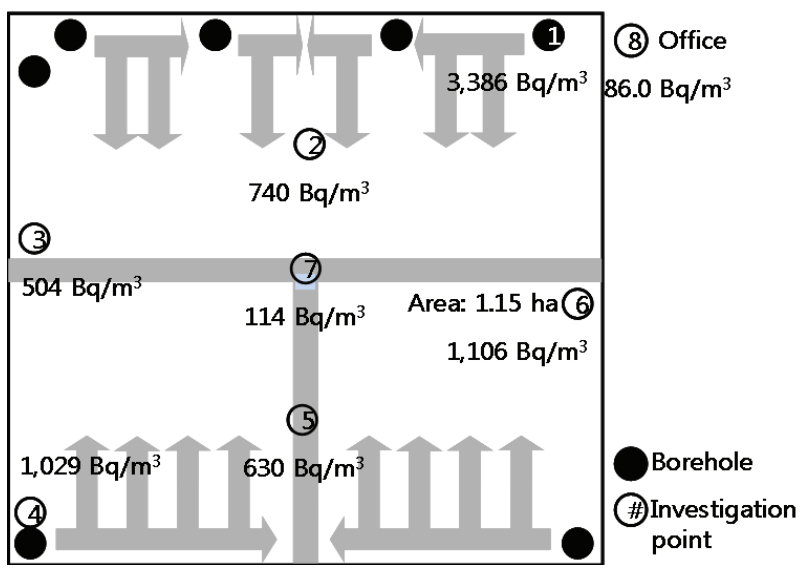

Fig. 4. The long term radon concentrations measured with SSNTDs in the $G$ site greenhouse
Site 1

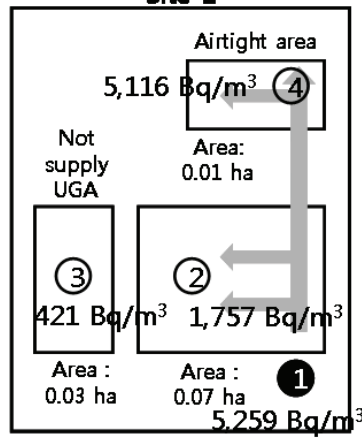

$5259 \mathrm{Ba} / \mathrm{m}$
Site 2

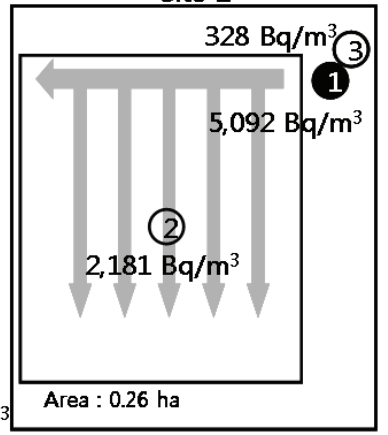

Site 3

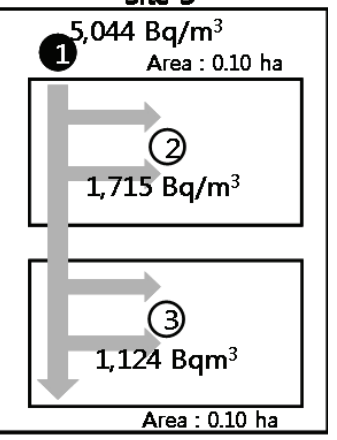

Borehole (\#) Investigation point

Fig. 5. The long term radon concentrations measured with SSNTDs in the $H$ site greenhouse (UGA: Underground-air)

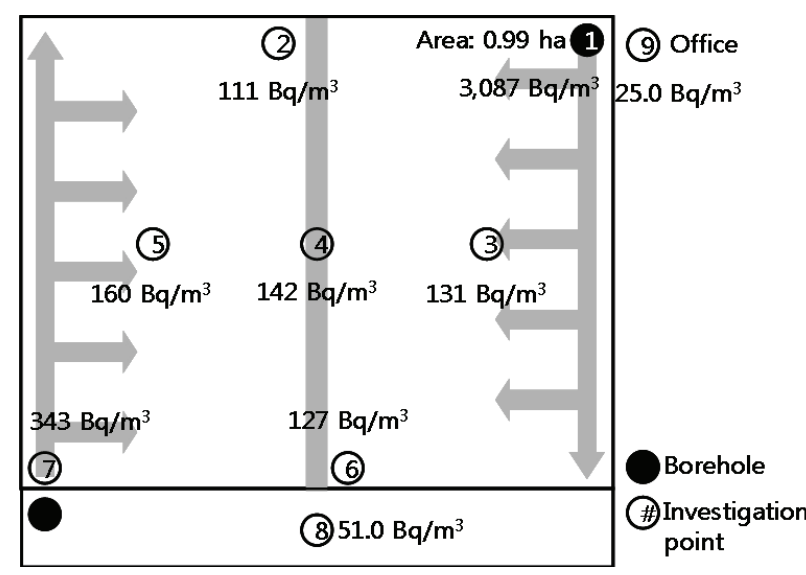

Fig. 6. The long term radon concentrations measured with SSNTDs in the $\mathrm{K}$ site greenhouse

높았기 때문인 것으로 판단된다. $\mathrm{H}-1$ 온실인 경우, 지하공 기 이용 공간인 유리온실 및 난 분화실과 지하공기 미이용 공간인 유리온실로 구분되고, 특히 면적이 작고 완전 밀폐 된 난 분화실의 라돈 농도는 지하공기 유입구와 비슷한 값
을 보였다. $\mathrm{H}-3$ 온실은 하나의 지하공기 이용 시설에 의 해 두개의 온실로 지하공기가 공급되는 연동식으로 지하 공기 유입구에서 가까운 온실의 라돈 농도가 약 $34 \%$ 정도 높았다.

능동형 연속측정 검출기를 이용하여 측정된 지하공기 이 용 시설의 가동에 따른 유입구 라돈 농도의 분포는 3,332 $17,900 \mathrm{~Bq} / \mathrm{m}^{3}$ 의 범위로 지역적인 특성을 보였다(Fig. 7). 지 하공기 유입구의 라돈 농도가 가장 낮은 F 시설은 협재 지역 으로 지질층서에 의하면 장석 감람석 현무암과 현무암 사이 에 화산쇄설층으로 구성되었으나 화산쇄설층 내 점토 함유량 이 높아 찬공수 누수가 발생되지 않아 지하 공기층의 발달이 어려워 암석으로부터 방출된 라돈의 유동이 상대적으로 원활 하지 못하고, 지하공기 이용 시설 시추공의 깊이가 깊지 않기 때문에 다른 시설들에 비해 낮았을 것으로 생각된다. 반면, 지하공기 유입구의 라돈 농도가 가장 높은 L 및 $\mathrm{M}$ 시설은 $\mathrm{F}$ 시설과 지질 특성은 유사하지만 지하 하부에 기반암으로 화 강암이 분포하고 현무암 구간 중 절리대가 형성되어 있어 통 기성이 좋기 때문에 암석으로부터 방출된 라돈의 유동이 상 대적으로 원활하여 라돈 농도가 높은 것으로 생각된다(Park 
and Kwon, 1993). 지하공기 유입구의 라돈 농도는 암석 내

${ }^{226} \mathrm{Ra}$ 함량, 지하공기 통기층 존재여부 등의 지질 특성, 지하
공기 이용 시설의 가동 빈도, 그리고 시추공 깊이에 영향을 받는 것으로 판단된다.

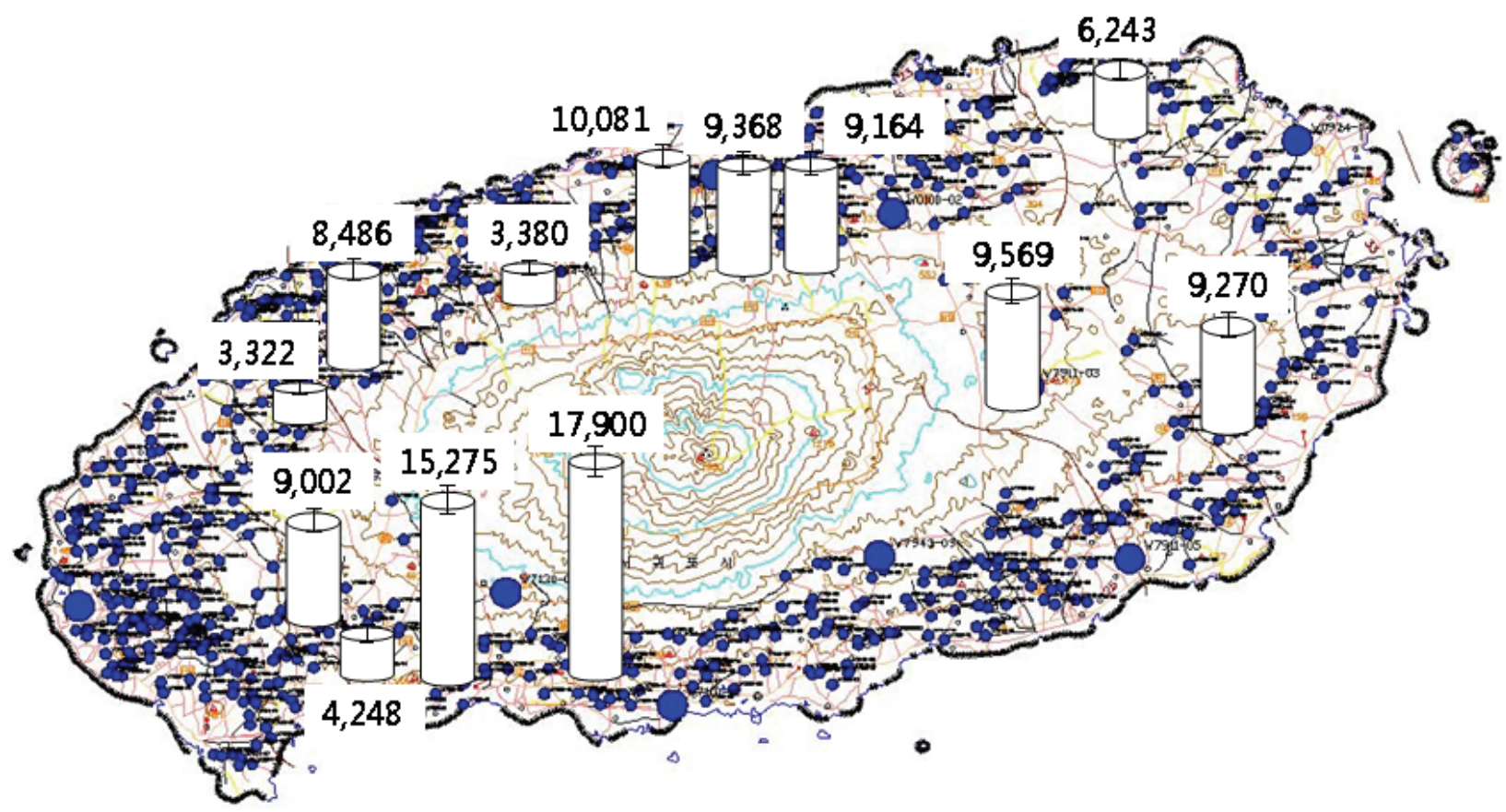

Fig. 7. The distribution of the instantaneous radon concentrations $\left(\mathrm{Bq} / \mathrm{m}^{3}\right)$ measured with CRM for underground-air borehole in the greenhouses

본 연구 결과로부터 지하공기를 이용하는 농업 시설의 온 실 내 라돈 농도는 지하공기 이용 시설의 가동 시간과 매우 밀접한 관계가 있었으며, 또한 지하공기 이용 시설의 수와 온 실 면적 그리고 환기에도 영향을 받는 것으로 확인할 수 있었 다. 그리고 온실 내 라돈 농도는 불균일하게 분포하며 지하공 기 유입구로부터 멀어질수록 낮아지는 경향을 확인할 수 있 었다. 한 개 지점의 농업 시설을 제외한 온실 내 라돈 농도는 국제방사선방호위원회(ICRP)에서 권고하는 근무지에서의 라 돈 참조준위 $1,000 \mathrm{~Bq} / \mathrm{m}^{3}$ 보다 낮았으나(ICRP, 2009), 본 연구를 수행한 특정 기간에 조사된 라돈 농도만으로는 작업 자들의 라돈 흡입에 의한 건강 위해성을 평가하기에는 무리 가 있었다. 따라서, 앞으로 온실 내 라돈 농도에 크게 영향을 미치는 지하공기 이용 시설의 가동 빈도에 따른 계절적 변화 및 재배 작물의 생장 주기와 같은 온실 환경 조건 등을 고려 하여 더욱 많은 시설을 대상으로 체계적이고 장기적인 연구 가 필요한 것으로 판단된다.

\section{요 약}

본 연구는 제주지역에서 온실 내 냉난방 및 $\mathrm{CO}_{2}$ 공급 목 적으로 지하공기를 이용하는 14 개 농업 시설을 대상으로 약
3개월 동안 지하공기 이용 온실과 미이용 공간 내 라돈 농도 및 지하공기 이용 시설의 가동에 따른 지하공기 유입구 내 라 돈 농도 분포를 조사하였다. 장기간 라돈 농도는 수동형 알파 입자비적 검출기(Raduet, Radosys Ltd., Hungary)로, 실 시간 라돈 농도는 능동형 연속측정 검출기(RAD7, Durridge Co., USA)를 이용하여 측정하였다. 지하공기 이용 온실 내 라돈 농도는 지하공기 미이용 공간과 국내 가옥의 실내 평균 값보다 높은 범위였으며, 대부분 농업 시설에서는 국제방사선 방호위원회에서 권고한 근무지에서의 참조준위 $1,000 \mathrm{~Bq} / \mathrm{m}^{3}$ 보다 낮은 반면 한 개 지점에서는 높은 결과를 보였다. 장기 간 및 실시간 지하공기 이용 시설의 가동에 따른 유입구의 라 돈 농도 분포는 각각 1,228 5,259 및 3,322 17,900 Bq/m 범위로 지역적인 차이를 보였다. 본 연구 결과, 지하공기 중 라돈 농도는 농업 시설이 위치한 지역의 지질 특성 및 시추공 깊이와 밀접한 관계가 있을 것으로 판단된다.

\section{감사의 글}

This study was supported by the Jeju Regional Environmental Technology Development Center (Project No. 10-2-70-73) and National Research Foundation of Korea (Project No. 2010-0020077), Republic of Korea in 2010. 


\section{참고문헌}

Abd El-Zaher, M., Fahmi, N.M., El-Khatib, A.M., 2008. Risk assessment from radon gas in the greenhouses. in: IXRadiation Physics \& Protection Conference, 15 19 November 2008, Nasr City, Cairo, Egypt.

Booh, S.A., Jeong, G.C., Park, C.K., 2006. Marking mechanism of Jeju using preventing groundwater, Proc. Kor. Soc. Eng. Geol. 4, 177-186.

Hulber E., 2009. Overview of PADC nuclear track readers. Recent trends and solutions, Radiat. Meas. 44, 821-825.

lyogi, T., Hisamatus, S., Inaba, J., 2006. ${ }^{222} \mathrm{Rn}$ concentration in greenhouse in Aomori Prefecture, Japan, Sci. Total Envir. 354, 142-149.

Kang, B.R., Kim, G.P., Kim, S.J., 2009. Characteristics of regional underground air distribution for various geothermal utilization, Rep. JERI, Vol. 2, 223-237.
Kim, Y.J., Chang, B.U., Park, H.M., Kim, C.K., Tokinami, S., 2011. National radon survey in Korea, Radiat. Prot. Dosim. 146, 6-10.

Korea Institute of Nuclear Safety (KINS), 2009. Radiation environment in the Korea, p. 171.

Oh, J.Y., Yi, S.S., Yoon, S., Koh, G.W., Yun, H.S., Lee, J.D., 2000. Subsurface stratigraphy of Jeju Island, J. Geol. Soc. Korea 36(3), 181-194.

Park, J.B., Kwon, S.T., 1993. Geochemical evolution of the Cheju volcanic island: Petrography and major element chemistry for stratigraphically-controlled lavas from the northern part of Cheju Island, J. Geol. Soc. Korea 29(1), 39-60.

Tokonami, S., Takahashi, H., Kobayashi, Y., Zhuo, W., Hulber, E., 2005. Up-to-date radon-thoron discriminative detector for a large scale survey, Rev. Sci. Instrum. 76, 113505. 